\title{
Shoreline and surface area changes induced by floating islands in peatland lakes (Tuchola Pinewood Forest, Poland)
}

\author{
Grzegorz Kowalewski \\ Department of Biogeography and Palaeoecology A. Mickiewicz University, Poznań, Dzięgielowa 27, 61-680 Poznań; \\ e-mail: ichtys@amu.edu.pl
}

\begin{abstract}
Multitemporal aerial photography and topographic maps were applied to investigate shoreline and surface area changes induced by floating islands in three small (area $<1$ ha) peatland lakes in the Tuchola Forest. The observation period covers the last 60 years (1951-2011). Shorelines of peatland lakes are stable, unless parts of them detach as floating mats and become floating islands which could have migrated sporadically in the past. Currently, they are rooted permanently to the mat (Dury I and Dury V Lakes) or float loose (Kozie Lake). In the observation period, movement of the islands and closing of lake bays due to overgrowing were the main reasons of shoreline changes. Due to low resolution of old aerial photographs, other changes are not decipherable and can be treated as negligible. Therefore, no reasonable conclusions can be drawn regarding the actual floating mat encroachment during the last 60 years, and the rate of lake shrinking, based of aerial photographs.
\end{abstract}

Keywords: peatland lake, floating mat, floating island, lake shoreline changes, lake shrinking, Tuchola Forest

\section{Introduction}

Peatland lakes are valuable natural objects, often subject to legal protection. They usually develop in closed-basin kettle-holes growing over from the shore with peatland mat, mainly composed of Sphagnum mosses. Unique features of such aquatic-wetland systems include: rare flora and fauna belonging to the Boreal, or even Arctic zone (Tobolski 2003), specific sedimentation process (Tobolski 2003, Kowalewski, Żurek 2011), exceptional effect of the sediment filling the basin on physiochemical conditions of lake waters (Banaś 2010; Banaś et al. 2012), and a specific coastal zone developed by floating mat. The latter feature provides specific lake overgrowth conditions. In the classic model, a lake's surface area decreases as a result of expansion of rushes from the shore and simultaneous filling of the basin with sediment. In the case of peatland lakes, the shrinking rate depends on expansion of the floating mat under which water is still present. When the floating mat grows over the entire water surface, a water gap remains under it.

Although peatland lakes located in outwash plains are usually small, and therefore particularly prone to rapid shrinking and shallowing, changes in their shorelines occur very slowly. The reason for this is low productivity of the lake waters and the encroaching peatlands, conditioned by low fertility of the catchment and low water $\mathrm{pH}$. The shape of the shoreline of those lakes, however, is sometimes subject to violent, significant changes resulting from movement of detached floating mat fragments, developing floating islands. These phenomena are either continuous or episodic. Peatland lakes are very small, and floating mat fragments are of tiny size at the landscape scale. Therefore, remote observation (by means of aerial and/or satellite photographs) of such changes posses a number of difficulties. They were only presumed ${ }^{1}$ in the earlier paper by the author (Kowalewski 2003). However, there was no time back then for a field survey on Lake Kozie IV, the unique character of which is determined by floating islands. The remaining two out of three objects presented in this paper were well-known to the author. However, even field observation could not reveal the existence of the phenomenon of float-

1 "It must be considered however, that some pieces of floating peat flow over the area and they could anchor at the place of the highest growth". 
ing island migrations. In Lakes Dury, floating islands are permanently rooted, constituting a stable floating mat fragment. Based on aerial photographs (at a scale 1:20 000 - 26000 ), where floating islands occupy only several hundred pixels (100-300), distinguishing them from the floating mat surrounding the water is practically impossible. Because the islands are usually located at a distance of several centimeters from the shore, and the size of one pixel in an aerial photograph is $90 \mathrm{~cm}$, they appear to merge with the floating mat. Only recognizing the phenomenon of floating islands during field works conducted within the scope of the project N N305 083935 made the author realise that the same mechanism also explains shoreline changes in peatland lakes on which no floating islands occur currently, but they could have migrated in the past.

The objective of this paper is to present shoreline changes in peatland lakes induced by movement of floating mat fragments. The study also aims at analysing the rate of changes in lake surface areas within the last 60 years on lakes in the "Jeziorka Kozie" and "Jeziorka Dury" reserves, located in the central part of the Tuchola Forest (Fig. 1). The study was conducted

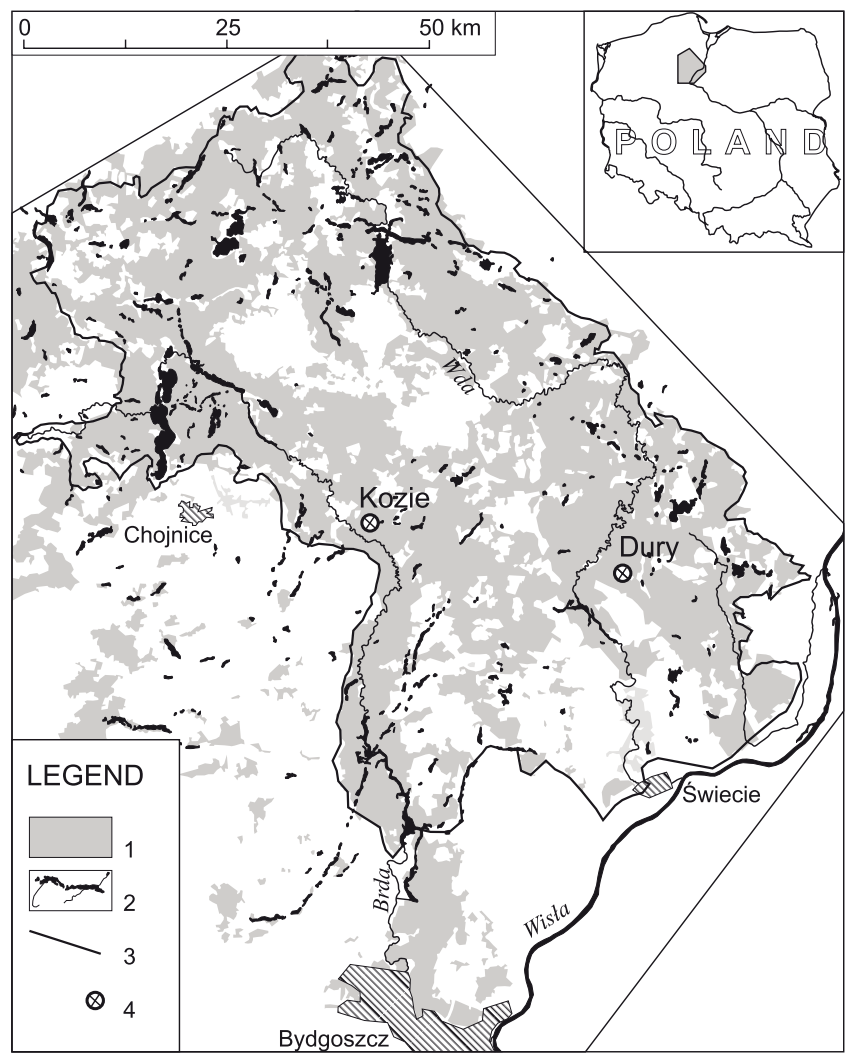

Fig. 1. Location of sites investigated: 1 - forest, 2 - lakes and rivers, 3 - boundary of the Tuchola Pinewood acc. to Kowalewski (2002), 4 - sites under investigation on three lakes (numbers following Kowalewski 2003):

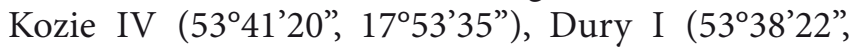

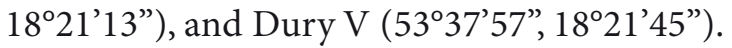

\section{Materials and methods}

\section{Remotely sensed imagery}

- Historic black and white aerial photography from 1951 (after rectification 1 pixel corresponds to 86$90 \mathrm{~cm}$ ) and 1976 (after rectification 1 pixel corresponds to $126-129 \mathrm{~cm})$.

- Oblique aerial photography taken on 31.05.2011 for the purposes of the project by means of a nonmetric camera (after rectification 1 pixel corresponds to $4 \mathrm{~cm}$ ).

Maps and geodetic measurements

- Topographic, Prussian maps at a scale of 1: 25 000 (the old and new numbers of sheets and year of preparing are given in brackets): Osche (984; 2376) (year 1910), Schüttenwalde $(981 ; 2373)$ (year $1874 \mathrm{a}$ ). The sheets signed with "a" are described as older ones and not of full value ("ältere, nicht vollwertige Aufnahme") in the collective table of topographic maps presented in the book "Das Reichsamt für Landesaufnahme und seine Kartenwerke" from 1931 (Verlag des Reichsamts für Landesaufnahme/Berlin NW 40).

- Topographic maps at a scale of 1: 10000 (geodetic coordinates 1965) prepared in the years 1979-1986.

- Field geodetic measurements were done with a tachymeter RTS $685 \mathrm{~L}$ in the local coordinate system for both Lakes Dury V and Kozie IV. Points determining the shoreline were imported to TNTmips programme, and georeferenced. The geodetic measurements accurately reflected the shoreline digitized from aerial photograph.

All images were georectified to the geodetic coordinates 1992, using a linear affine transformation model and nearest neighbour resampling. Each model was based on shoreline-defined image-based control points. Therefore, the determined delineation and area change show only relative modifications, and do not meet geodetic precision. Oblique photographs were subject to prior manual geometric correction in Adobe Photoshop programme by means of transform, scale, and expand tools, matching the shape of the floating mat boundary to the shoreline until full compatibility. Lake boundaries were digitized manually from aerial photographs. 
Precise delineation of the water bodies was difficult due to low resolution of the monochromatic images. The boundary between the mat and water appeared rather in a form of a blurred zone of 1-3 m width (2-4 pixels) than a sharp line (as it is in the 2011 images), particularly in places where the water line was indented with zigzagging and meandering lines. To enhance the precision of manual digitalization, a computer-based Feature Mapping classification technique was used to extract the lakes' waterlines on monochromatic images.

High resolution of adjusted oblique aerial photographs from 2011 allowed for detailed mapping of the shorelines. The inner and outer lake margins were distinguished (along with inner and outer areas, respectively, in Table 1), and their means were calculated. The inner water line is the boundary between the water surface and vegetation growing at the floating mat, mainly developed by white beak-sedge (Rhynchospora $a l b a$ ). The outer shore is dense floating mat cover.

\section{Results}

Shoreline changes in the lakes studied within the last 60 years (1951-2011) were mainly induced by movement of floating islands. In the remaining sections of the shorelines, their expansion or retreat was recorded, but to such a small extent that it could not be treated as reliable in view of the limited accuracy of available aerial photographs. Comparison of changes in the size of the lakes studied is presented in Table 1.

\section{Surface area changes}

\section{Lake Kozie IV}

The surface area of the lake in the aerial photograph from 1951 (Table 1, Fig. 2), obtained by means of manual digitalization, was calculated at $6666 \mathrm{~m}^{2}$. The surface area obtained by means of the feature mapping method (1951) amounted to $6648 \mathrm{~m}^{2}$ (Fig. 3). This value includes the lake's surface area $\left(6235 \mathrm{~m}^{2}\right)$, bays in its north-eastern part $\left(63 \mathrm{~m}^{2}\right)$, and the sum

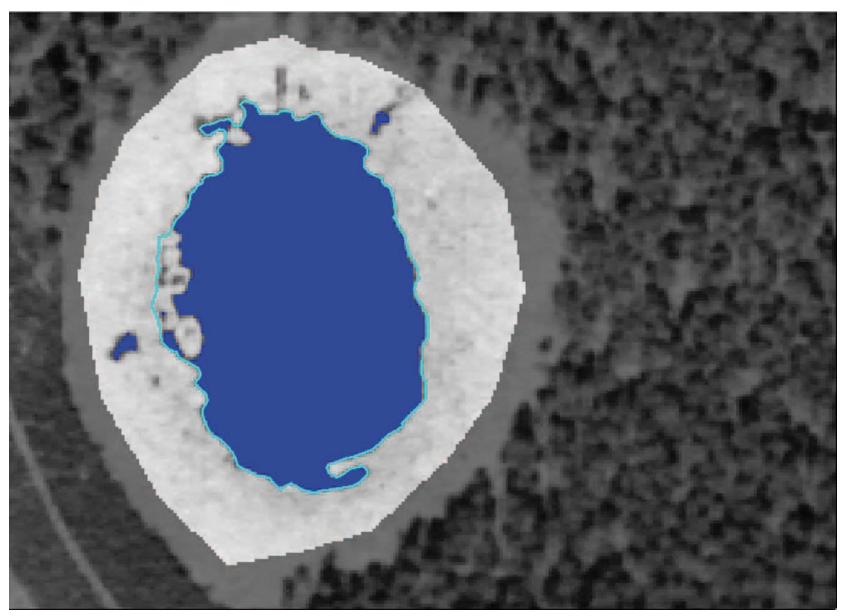

Fig. 3. Screen capture of Lake Kozie IV from an aerial photograph taken in 1951. Blue area - result of feature mapping within the range of 0-80 of grey scale. Light blue line - digitalized water line of the lake in 1951.

of surface areas of islands $\left(350 \mathrm{~m}^{2}\right.$ - surface area was calculated precisely in the photograph from 2011 and adopted to calculation on 1951 photograph with the assumption of its stability throughout last 60 years). The difference between vector and raster mapping amounted to $6666-6648=18 \mathrm{~m}^{2}$, i.e. $0.27 \%$.

The difference in the measurement of the surface area between 1951 and 2011 (60 years) suggests its decrease by $2.7 \%$. Should the calculation for 2011, however, consider the surface area of the cut off bay $\left(25 \mathrm{~m}^{2}\right)$, the difference would be reduced to $2.3 \%$. The dynamics of the floating mat shoreline are presented in Fig. 2. The most significant changes occurred in the southern part of the lake, where the end of the peninsula came close to the shore, closing the bay (letter $\boldsymbol{a}$ in Fig. 2). The highest floating mat growth (no more than $2 \mathrm{~m}$ ) was determined at the northern shore of the peninsula $(\boldsymbol{b})$ closing the bay. This probably results not from mat encroaching, but from movement of the peninsula itself. A possible reason for the peninsula migration is an impact of a floating island. Only in

Table 1. Comparison of the lakes' surface areas at various times.

\begin{tabular}{|c|c|c|c|c|c|c|c|c|}
\hline \multirow{3}{*}{ Lake } & \multicolumn{4}{|c|}{ Lake area $\left[\mathrm{m}^{2}\right]$} & \multicolumn{4}{|c|}{ Difference in area $\left[\%\left(\mathrm{~m}^{2}\right)\right]$} \\
\hline & \multirow{2}{*}{1951} & \multicolumn{3}{|c|}{2011} & \multicolumn{3}{|c|}{$1951-2011$} & 2011 \\
\hline & & outer & inner & mean & outer & inner & mean & (outer-inner) \\
\hline Kozie & 6666 & 6508 & 6464 & 6486 & $2.37(158)$ & $3.03(202)$ & $2.70(180)$ & $0.7(45)$ \\
\hline Dury I & 5232 & 5171 & 4989 & 5080 & $1.16(61)$ & $4.64(243)$ & $2.90(152)$ & $3.5(182)$ \\
\hline Dury V & 8720 & 8619 & 8389 & 8504 & $1.15(101)$ & $3.79(331)$ & $2.47(216)$ & $2.9(230)$ \\
\hline
\end{tabular}




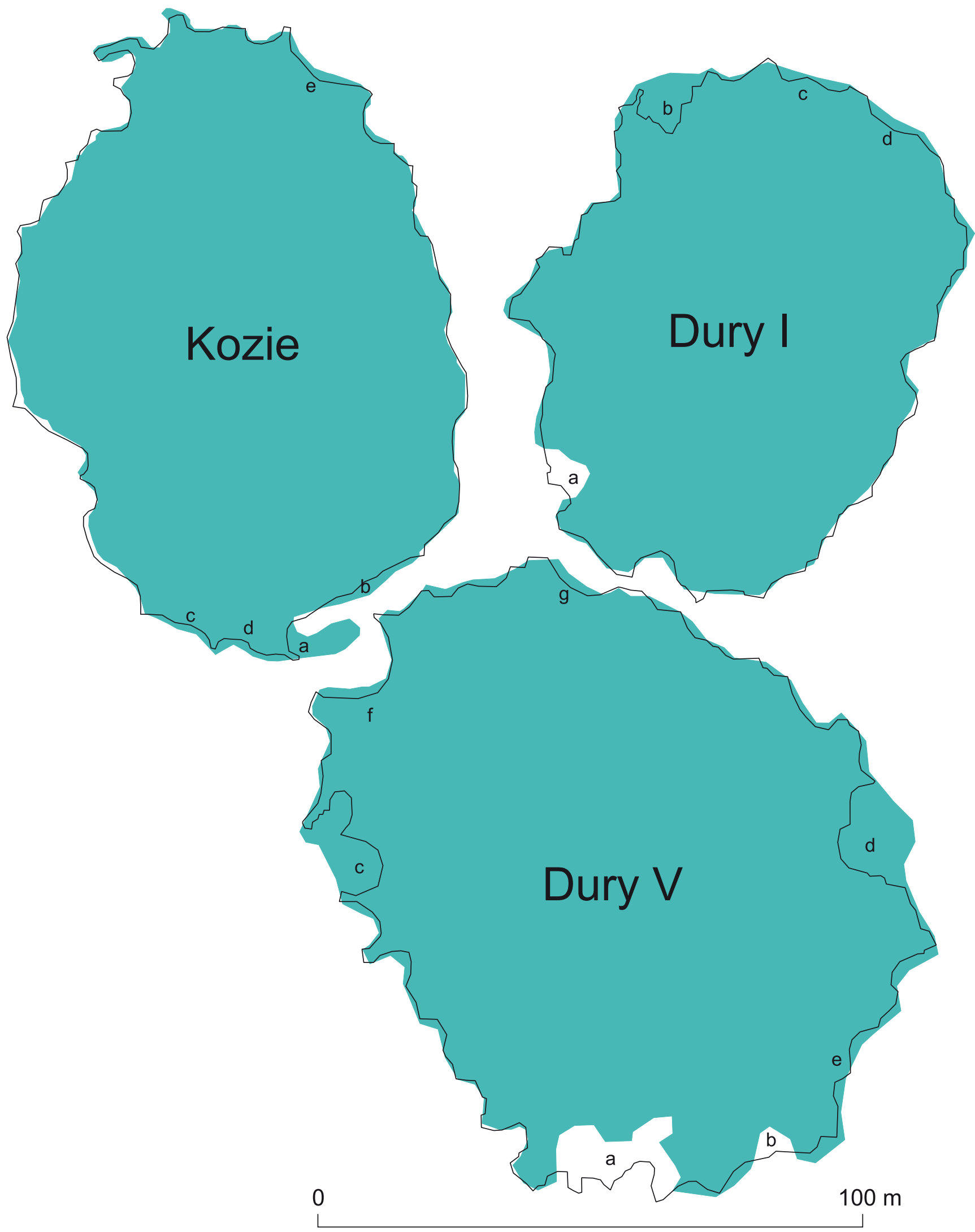

Fig. 2. Comparison of surface area in 1951 (colour) and 2011 (outline of outer water line). In Lake Kozie IV, lake islands are not included. Explanation of letters - see text. 
three sections of the shoreline, the changes amounted to approx. 1-1.5 $\mathrm{m}(\boldsymbol{c}, \boldsymbol{d}, \boldsymbol{e})$. Growth of the floating mat can result from changes in its internal structure. Numerous small waterholes with a width of $0.5-1.5 \mathrm{~m}$, probably of frost origin, developed here. This could have caused shoreline migration.

Although the calculated decrease in the lake's surface area amounted to $2.3 \%$ during 60 years, determination of the potential rate of the lake's diminishment based on this value can involve a large error. The main reason for this is measurement accuracy. An error of only 1 pixel in the case of shoreline with a length of $383 \mathrm{~m}$ (in 1951) results in a difference in the surface area at a level of $345 \mathrm{~m}^{2}$, i.e. $5 \%$ of the lake (error $=383 \mathrm{~m} \times 0.9 \mathrm{~m}$ pixel size). This value is much higher than the change calculated. Because in monochromatic images the water-floating mat boundary constitutes a zone with a width of 1-3 m, such an error is possible. Comparison of the shoreline between 1951 and 2011 reveals both zones of increase and decline of the floating mat's range. The values are usually much lower than $1 \mathrm{~m}$, i.e. below the value of a potential error. The situation is analogical to that in the case of Lakes Dury I and Dury V.

\section{Lake Dury I}

The lake's surface area in the aerial photograph from 1951 (Table 1, Fig. 2), obtained by means of manual digitalization, was calculated at $5232 \mathrm{~m}^{2}$ (Fig. 4).

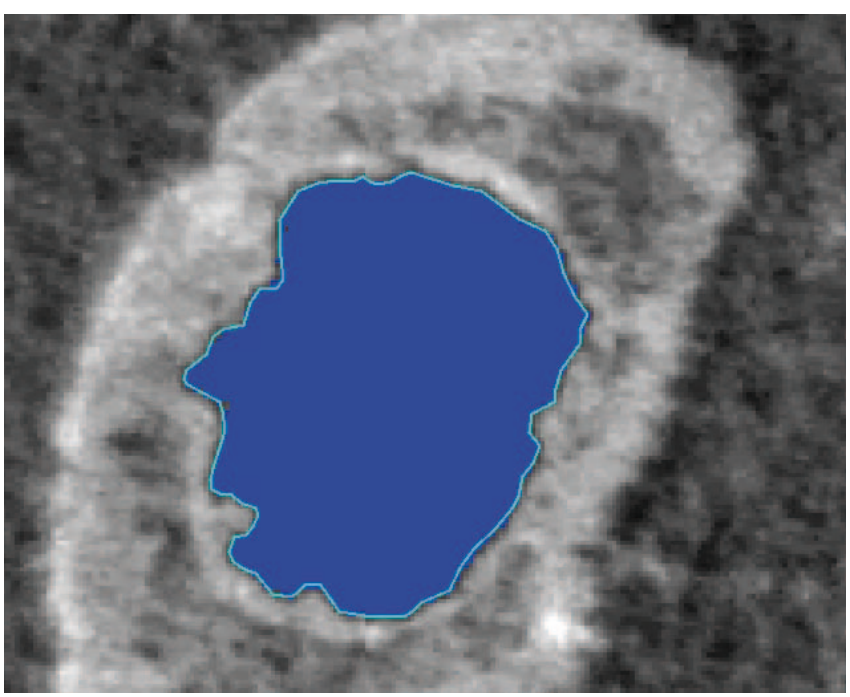

Fig. 4. Screen capture of Lake Dury I from an aerial photograph taken in 1951. Blue area - result of feature mapping within the range of 0-62 of grey scale. Light blue line - digitalized water line of the lake in 1951.
The surface area obtained by means of feature mapping amounted to $5255 \mathrm{~m}^{2}$. The difference between vector and raster mapping was 5232-5255 $=-23 \mathrm{~m}^{2}$, i.e. $0.44 \%$.

The difference in the measurement of the surface area between 1951 and 2011 (60 years) suggests its decrease by $2.9 \%$. The dynamics of the floating mat shoreline is presented in Fig. 2. The most significant change occurred as a result of movement of floating mat fragments from the south-western (letter $\boldsymbol{a}$ in Fig. 2) to the north-western part of the lake (b). The outline of the migrating mat fragments in their new location (2011) occupies an area larger than that in the photograph from 1951. This influenced the total surface area change to the largest extent. Reasons for this change were not explained due to very low resolution of the photograph from 1951. The most significant floating mat growth was observed in the northern part of the lake $(\boldsymbol{c}, \boldsymbol{d})$.

\section{Lake Dury V}

The lake's surface area in the aerial photograph from 1951 (Table 1, Fig. 2), obtained by means of manual digitalization, was calculated at $8720 \mathrm{~m}^{2}$ (Fig. 5). The surface area obtained by means of feature mapping amounted to $8661 \mathrm{~m}^{2}$. The difference between vector and raster mapping was $8720-8661=59 \mathrm{~m}^{2}$, i.e. $0.68 \%$.

The difference in the measurement of the surface area between 1951 and 2011 (60 years) suggests

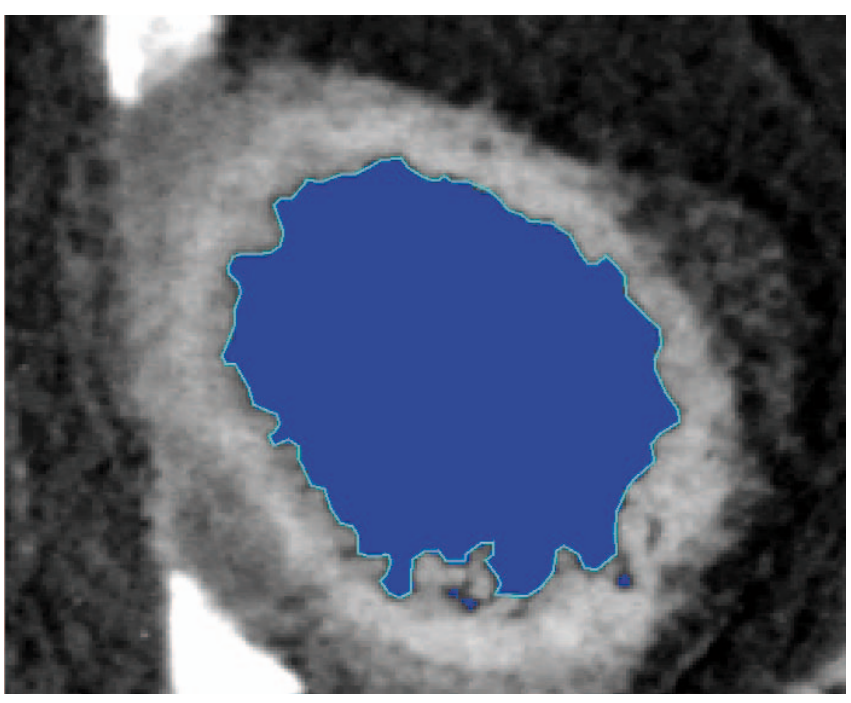

Fig. 5. Screen capture of Lake Dury V from an aerial photograph taken in 1951. Blue area - result of feature mapping within the range of 0-61 of grey scale. Light blue line - digitalized water line of the lake in 1951. 
its decrease by $2.5 \%$. The dynamics of the floating mat shoreline is presented in Fig. 2. The most significant change resulted from movement of floating mat fragments from the lake's southern part (letter $\boldsymbol{a}$ in Fig. 2) to the western $(\boldsymbol{c})$ and eastern shore $(\boldsymbol{d})$, and movement of a floating mat fragment $(\boldsymbol{b})$ in the southern part of the lake. The most significant floating mat growth occurred in the coastal part $(\boldsymbol{e}, \boldsymbol{f}, \boldsymbol{g})$. The open space between the mat and its detached fragments, impossible to determine in aerial photographs due to their low resolution, makes it difficult to estimate the actual floating mat growth rate for the entire lake.

\section{Parameters of floating islands}

\section{Lake Kozie IV}

On Lake Kozie, 6 floating islands exist, occupying the total area of $350 \mathrm{~m}^{2}$ (Table 2). Measurement of their surface area was performed based on the photograph from 2011. The photograph permitted precise determination of their shorelines. The islands move freely throughout the observation period. Their example location is presented in Fig. 6. The islands can migrate from one to the opposite end of the lake

Table 2. Morphological parameters of floating and rooted islands.

\begin{tabular}{|c|c|c|c|}
\hline lake & area $\left[\mathrm{m}^{2}\right]$ & area of Island $\left[\mathrm{m}^{2}\right]$ & islands ratio [\%] \\
\hline Kozie & 6486 & 350 & 5.4 \\
\hline Dury I & $5080^{*}$ & 68 & 1.3 \\
\hline Dury V & $8504^{*}$ & 266 & 3.1 \\
\hline
\end{tabular}

* including the area of permanently rooted islands

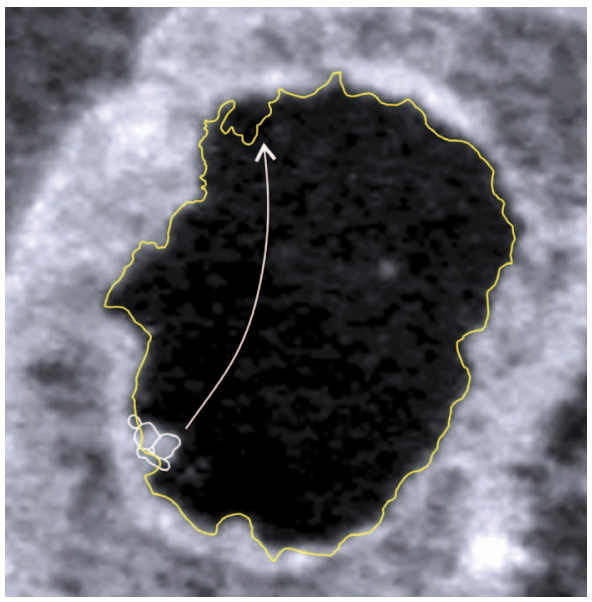

within one day. An experiment was conducted involving dragging an island from one to the opposite end of the lake using a rope tied to the shore. Initiation of movement of the island upwind required significant strength, but its further dragging did not require much effort owing to high inertia of the island.

\section{Lake Dury I}

On Lake Dury I, movement of floating mat fragments from the south-western to north-western part was determined (Fig. 7). The island (currently a peninsula) includes a waterhole with an area of $1 \mathrm{~m}^{2}$. The area of the entire island amounts to $48 \mathrm{~m}^{2}$, including the fragments already anchored to the floating mat. The island has a modular construction, as determined based on the photograph from 2011. It is composed of at least 4 parts, currently permanently connected. Their outlines, based on the photograph from 2011, are not compatible with the floating mat fragment detached later in the photograph from 1951 (Fig. 7). Perhaps the history of their migration and transformation is more complicated.

\section{Lake Dury V}

On Lake Dury V, islands migrations were more complicated than on Lake Dury I. The two largest islands, located at the southern shore in 1951, both with an identical area of $113 \mathrm{~m}^{2}$, migrated, one to the western, and the other to the eastern shore. The smallest fragment, also located at the southern shore, with an area of $40 \mathrm{~m}^{2}$, migrated later to their place (Fig. 8).

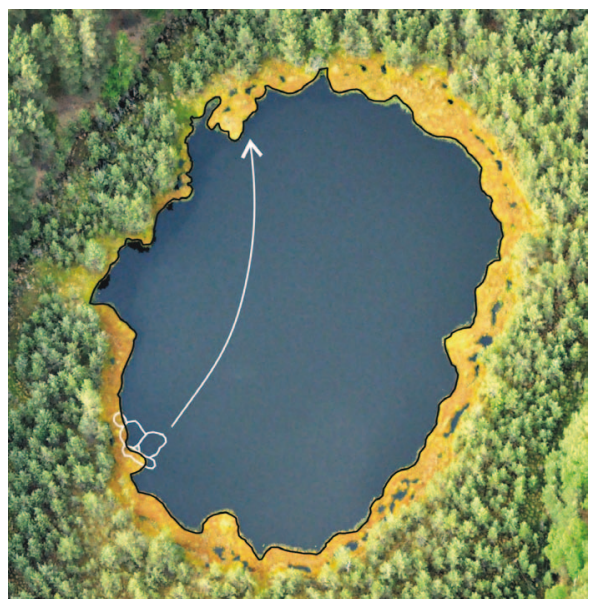

Fig. 7. Aerial photographs of Lake Dury I from 1951 (left) and 2011 (right) indicating movement of a group of floating islands. The migration route is hypothetical. 


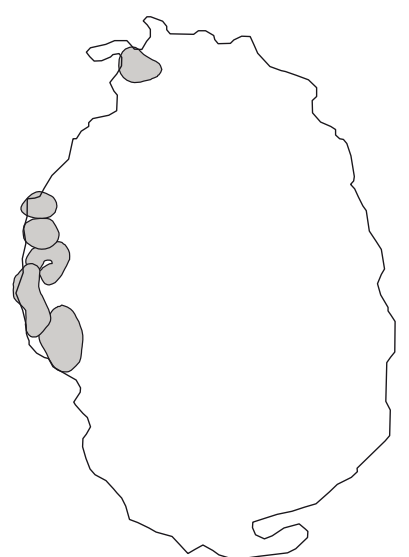

1951

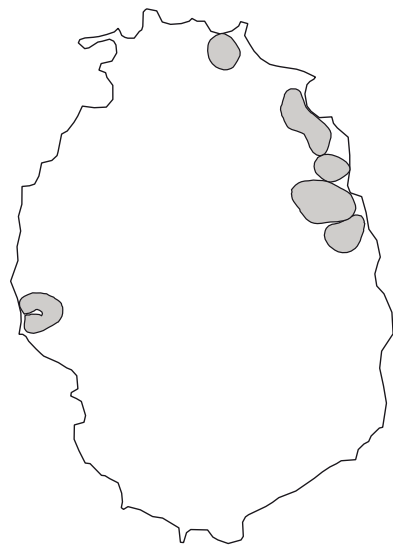

Techmex

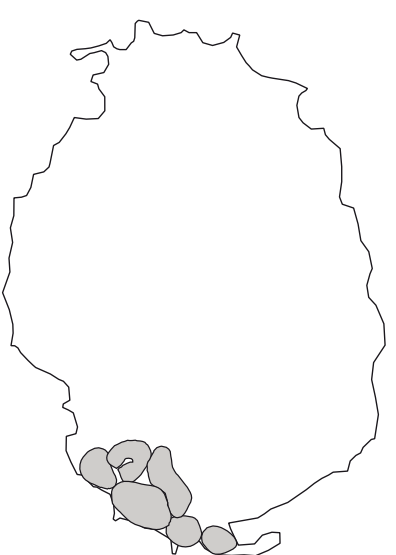

1976

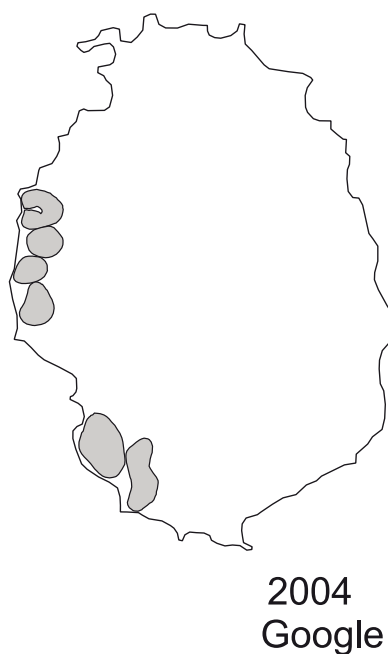

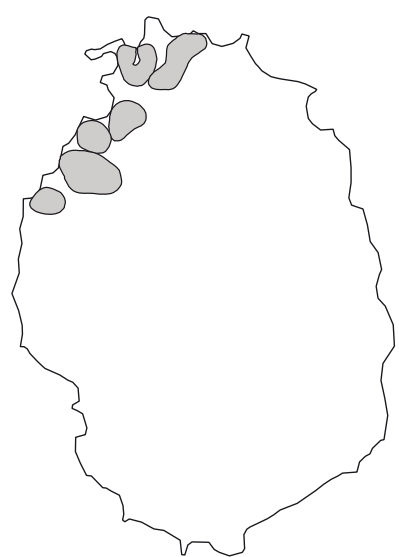

2005
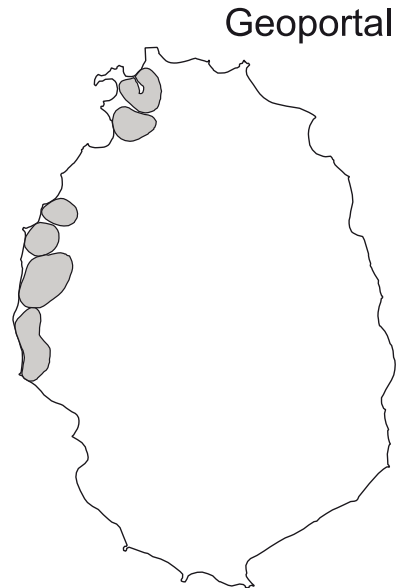

2011

Fig. 6. Location of floating islands in six different periods on Lake Kozie. In 1976 determination of the location probable due to low resolution of the photograph.
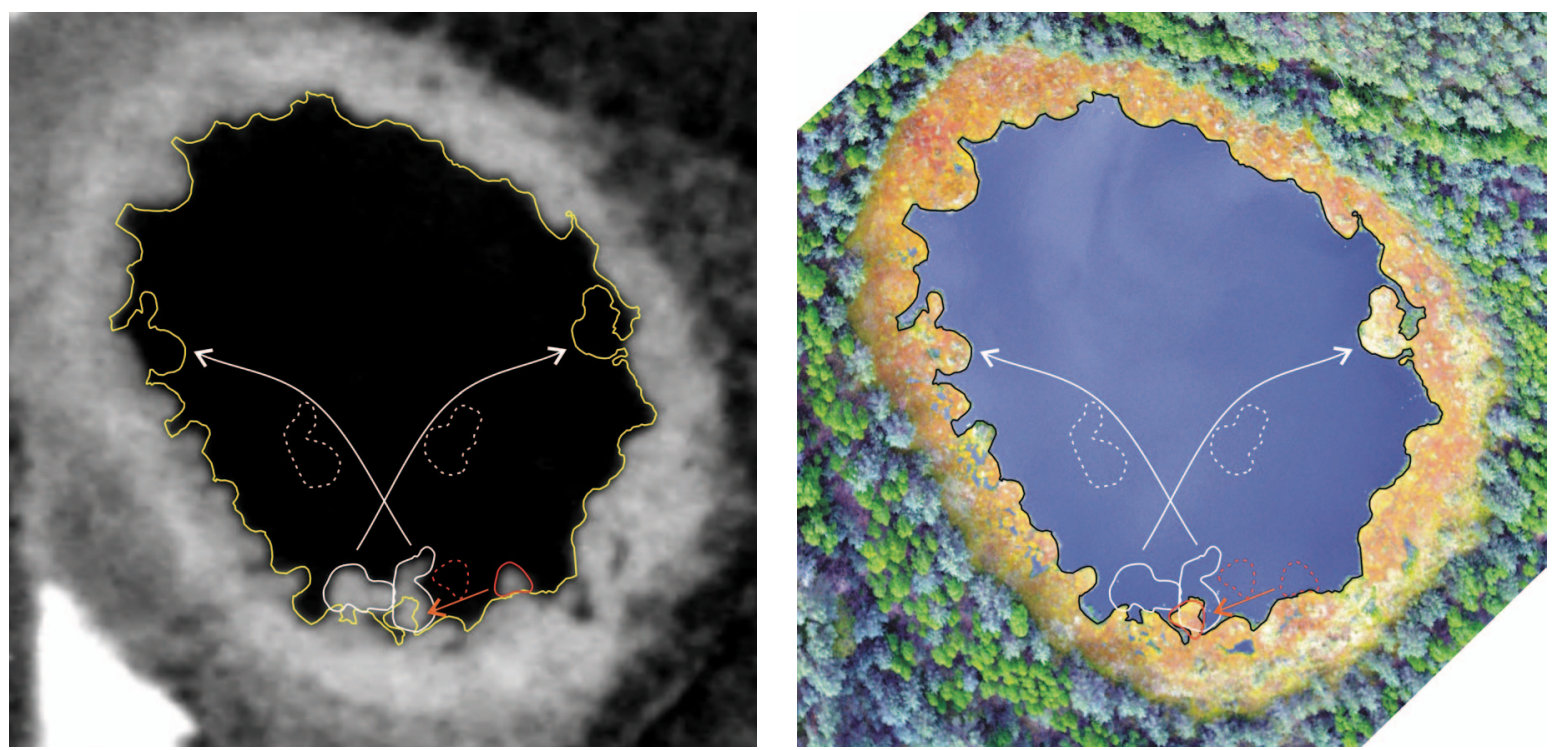

Fig. 8. Aerial photographs of Lake Dury V from 1951 (left) and 2011 (right) indicating movement of a group of floating islands. The migration route is hypothetical. 
Vegetation zone at the water-floating mat boundary

At the boundary of dense floating mat, mainly formed by Sphagnum mosses, coastal vegetation zone develops. It is dominated by Rhychospora alba and
Carex limosa. The largest clusters develop in bays and in shoreline segments with zigzagging and meandering waterline (Fig. 9).

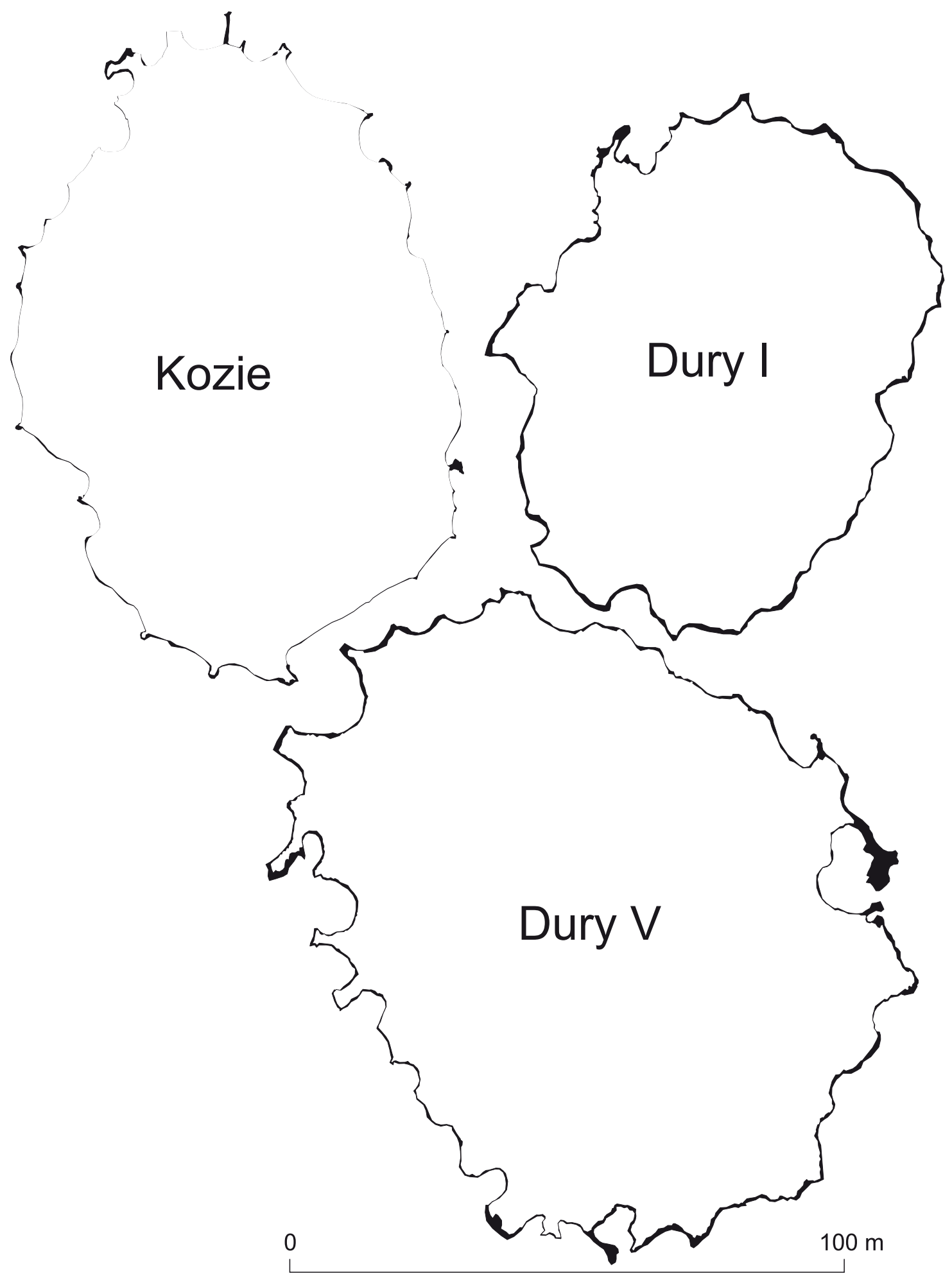

Fig. 9. Comparison of the inner and outer lake margin outlined on aerial photographs from 2011. 
The difference between the inner and outer lake margin in the case of lakes with permanently rooted islands amounts to 3.5\% (Dury I) and 2.7\% (Dury V), respectively. In the case of the lake with freely floating islands (Lake Kozie), it amounts to only $0.7 \%$, i.e. it is 4-5 times lower. Another difference concerns varied occurrence of coastal vegetation. In the case of Lakes Dury it occurs alongside all shores, and in Lake Kozie only in bays indented into the floating mat, where it is not destroyed by impacts of floating islands.

\section{Comparison of topographic maps}

The oldest source used for studying lake shoreline changes are topographic maps from the turn of the $19^{\text {th }}$ and $20^{\text {th }}$ century, published in Prussia. Their quality is basically good. The maps, however, include errors in the case of the Tuchola Forest. Lake Kozie is located on the Schüttenwalde sheet, prepared in the initial period of preparation of maps of this series. As was mentioned above, its precision in relation to other sheets was lower. It is confirmed by comparison of Prussian maps with a contemporary topographic map 1:10 000 from 1965 (Fig. 10), illustrating very high differences in the position and shape of peatlands (and lakes adjacent to peatlands). Therefore, drawing conclusions concerning surface areas of lakes based on this type of maps requires high caution.

Insufficient accuracy (compare chapter "Material and methods") does not concern the Osche sheet presenting Lakes Dury. Detailed comparison of contemporary and Prussian sheets, however, arouses a number of doubts. Although the location of peatlands is reflected with sufficient accuracy (Fig. 10), the lakes show significant changes in their shapes. This concerns Lakes Dury II, IV, and V. Only Lake Dury I showed no larger changes. It would be difficult to justify, however, why only one lake did not change, and the other lakes did. Geological evidence (Kowalewski \& Milecka 2003, Kowalewski \& Barabach 2010) reveals an opposite situation, showing high similarity of sedimentation processes in all of the lakes. Numerous geological drillings performed near the boundary between the floating mat and forest, also within the range of lakes from the Prussian map, suggest that the lake could not exist in that place 100 years ago.

In the case of Lake Dury V, a question arouse whether the significant retreat of the shoreline was influenced by forest clearing for the purpose of construction of the Zur-Gdynia power line, and its construction itself, executed in 1928. Works carried out within the range of the floating mat could largely affect its structure, but detailed geological analyses falsified the hypothesis on the lake's existence. Geological documentation shows a weakly decomposed peat layer with a thickness of more than $3 \mathrm{~m}$ in the place of the lake's range. Its sedention in such a short time was not possible. The range of the small lakes on the Prussian map should therefore be treated as unreliable.

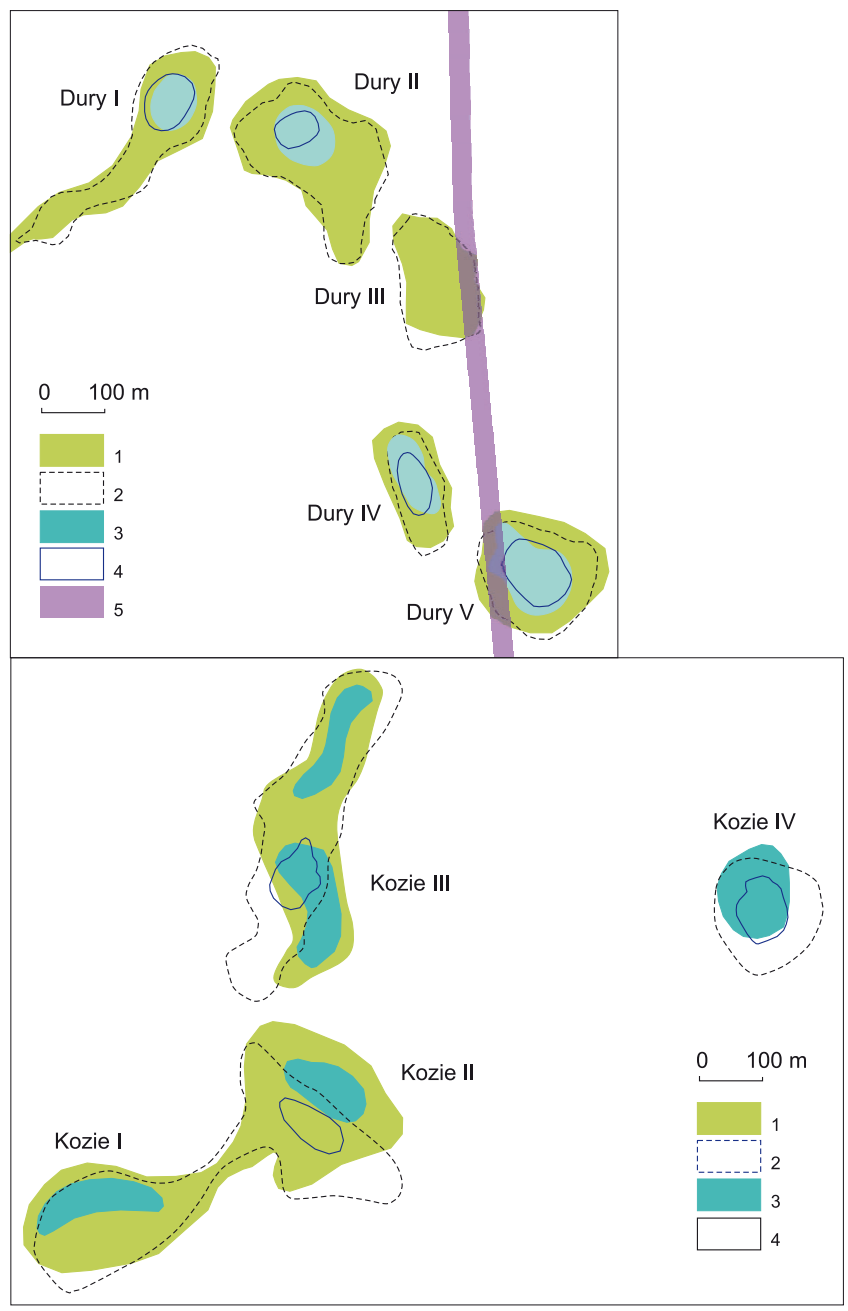

Fig. 10. An outline of the boundary of peatlands and lakes in the "Jeziorka Kozie" (bottom) and "Jeziorka Dury" (top) reserves comparison between old Prussian map from the end of the $19^{\text {th }}$ century and modern topographical map 1:10 000. Explanation: 1 - peatland area in the $19^{\text {th }}$ century, 2 - boundary of modern peatlands, 3 - lake surface area in the $19^{\text {th }}$ century, 4 - boundary of modern lakes, 5 - location of forest clearings due to construction of a power line. Numbers of lakes according to Kowalewski 2003. 


\section{Discussion}

Shoreline changes in peatland lakes have a course different than those occurring in lakes with no floating mat. The range of the latter shrinks as a result of filling the basin with sediment, and further development of rushes. The range of peatland lakes, however, can decline to zero while not being filled with sediment. The floating vegetation mat can cover the entire water surface, developing a water gap.

The specific form of lake shoreline, developed by floating vegetation, provides entirely different conditions of observation of shoreline changes in lakes. Contrary to lakes with no floating mat, where the shoreline migrates as a result of varying water level, simultaneously limiting the possibility of analysing its changes (Churski 1996, Choiński 2007), analysis of the changes in peatland lakes with floating mat is independent of the water level in the lake. According to the author, it is inaccurate to state, as in Turczyński et al. (2009), that "In case of lakes which are surrounded with a wide belt of floating vegetation mats or peat bogs it is exceptionally difficult to demarcate this boundary and as some field surveys show it can be almost impossible. In addition to that, the water from the lake enters the local depressions between clumps of vegetation. The hummock-hollow structure of organic landforms makes it difficult to mark out the shoreline." Such statements may result from observations conducted on objects where the character of vegetation and substratum suggest presence of floating mat which already lost its buoyancy. Lifting of floating mat was evidenced experimentally in the scope of the project ELARP (Taro et al. 2005), where the shoreline of a lake surrounded by floating mat did not change significantly after water level increase by $130 \mathrm{~cm}$. It is worth noticing that such a high increase in water level in lakes in natural conditions occurs sporadically. Also responses of peatland ecosystems in the zone of ground water table increase around artificial water bodies suggest similar tendencies (Kowalewski 2001).

Moreover, shoreline of peatland lakes is much more distinct, because the bottom structure in the coastal zone restricts development of high rushes which limit the possibility for precise determination of the shoreline to the largest extent (Turczyński et al. 2009). Shoreline distinctiveness is higher in lakes with floating islands. The islands effectively hinder vegetation development along the shoreline. Another element convenient from the point of view of analy- sis of shoreline changes is lack of trees and bushes in its direct vicinity. Reasons for this phenomenon were discussed in the paper by Kowalewski \& Barabach (2010). Direct geodetic measurements of the floating mat shoreline can be quite dangerous due to bending of the floating mat. During field works, in several cases, measurement turned out to be impossible. Such observations confirm those by Turczyński et al. (2009), suggesting usefulness (or even necessity) of application of teledetection materials. The authors cited discuss an interesting issue of shoreline position. They only recognise the zone under the floating mat filled entirely with sediment as the right shoreline ${ }^{1}$. This determination is accurate from the point of view of analysis of changes in water volume in the lake. From the point of view of analysis of changes in the surface area, however, there is no reason to adopt the zone of disappearance of the water gap under the floating mat as the shoreline. In the case of objects analysed in this paper, such a zone is distinguished quite precisely by the boundary zone between the floating mat and the marshy coniferous forest (Kowalewski \& Barabach 2010).

In spite of occurrence of a number of circumstances facilitating precise demarcation of the floating mat shoreline, its variability is difficult to determine. As evidenced in results of this study, the reason is very low resolution of archival aerial photographs in relation to their size. The paper reveals the difficulty of application of archival teledetection materials available in Poland for determination of changes in very small objects (below $1 \mathrm{ha}$ ). The study carried out only evidences that the dynamics of floating mat growth are so negligible, that they are certainly undetectable with the existing teledetection materials. Therefore, it is necessary to apply palaeogeographic and palaeoecological methods in order to trace longterm floating mat migrations. In order to determine shoreline changes throughout the period of 60 years analysed, it would be necessary to use high-resolution photographs (below one decimetre). The paper also evidences that application of older cartographic materials requires high degree of caution and verification of observed changes with another method.

The rate of changes estimated in the author's previous paper (Kowalewski 2003) was re-estimated for lakes in the "Jeziorka Dury" reserve. The results of

1 "The coat of floating vegetation mats moves the shoreline which can be seen on the aerial photographs towards the centre of the lake, thereby reducing the range of the open surface of the reservoir" 
a much more precise study, presented in this paper, based on more detailed teledetection materials, and focused on only three objects with observed shoreline changes induced by migration of floating islands, negatively verified the previous results.

Changes in the shoreline of the peatland lakes studied occurred mainly as a result of migration of detached fragments of floating mat and/or floating islands. Their detachment from the shore and anchorage in other places disturbs the unequivocal determination of dynamics of floating mat growth to a degree making its accurate estimation impossible. In the case of Lake Kozie, where islands still migrate, the determination is more precise. However, even in this case, low precision of the materials analysed does not permit reliable conclusions. According to the author, only such floating mat fragments can be recognised as a "floating island" which float at the moment of observation. Floating mat fragments for which past migrations were documented, but which are currently permanently anchored to the shore, can be described as permanently rooted floating islands.

The determined scale of changes in the period of 60 years, suggesting a decrease in the surface area at a rate of $0.05-0.07 \% / y e a r$, considering all aforementioned objections as to their precision, is a dozen or so times smaller than that for shallow eutrophic lakes (Choiński 2007). Such an index suggests the remaining time of existence of the lake amounting to 15002000 years. This value requires palaeogeographical verification.

The mean decline rate index of $0.05 \%$ /year was also obtained for Masurian lakes (Marszelewski \& Adamczyk 2004). However, those two studies cannot be compared for at least two reasons. Firstly, in the case of Masurian lakes, the mean value was calculated for large and small lakes, subject to anthropopressure to various extent, and often subject to artificial increase in their surface area. The lakes analysed in this paper are only subject to pressure of forest management. Secondly, results obtained for Masurian lakes were calculated based on topographic maps, analogical to those compared in this paper. As documented in Fig. 10, those maps are unreliable for the very small lakes studied. Their reliability for large lakes is certainly higher. A similar rate of shrinking of the lake $(0.06 \%)$ was also revealed for coastal lakes (citing Choiński 2007).

In conclusion, peatland lakes of the Tuchola Forest, belonging to the deciduous forest zone, are exceptionally stable systems. This contrasts with substan- tial changes occurring in lakes surrounded by floating mat of the Boreal and tundra zone. Their development occurs as a result of permafrost melting. This provides conditions for growth of floating peat mats at a rate of 1-2 m/year with simultaneous expansion of the shoreline at a rate of more than $0.5 \mathrm{~m} /$ year (Parsekian et al. 2011). The discontinuous permafrost zone undergoes significant changes in the number and surface area of lakes with a general negative tendency (Smith et al. 2005). For example, Yoshikawa and Hinzman (2003) found a reduction in thermokarst ponds exceeding $80 \%$ based on 1950 to 1981 aerial photographs. Klein et al. (2005) found a reduction in the surface area of a pond exceeding 70\% based on 1950 to 1996 aerial photographs. The main causes for those rapid changes were (Roach et al. 2011) talik drainage, evaporation, and terrestrialisation due to floating mat encroachment. All these mechanisms increased or developed as a result of climate warming. Riordan et al. (2006) found a reduction in the surface areas and number of shallow, closed-basin ponds in the discontinuous permafrost zone in Boreal regions. In the continuous permafrost zone, they evidenced negligible changes, as in lakes in the Tuchola Forest. This suggests high significance of stable environmental conditions for maintenance of unchanged state of lakes.

\section{References}

Banaś K., 2010, Morphology of peatland lakes. Limnological Review 10: 3-14.

Banaś K., Gos K., Szmeja J., 2012, Factors controlling vegetation structure in peatland lakes-Two conceptual models of plant zonation. Aquatic Botany 96: 42-47.

Choiński A., 2007, Physical limnology of Poland (original: Limnologia fizyczna Polski). Wydawnictwo Naukowe UAM (in Polish).

Churski Z., 1996, Kartowanie brzegów jezior i zbiorników (Mapping of the shores of lakes and reservoirs), [in:] Gutry-Korycka M., Werner-Więckowska H. (eds), Przewodnik do hydrograficznych badań terenowych (Guide for the hydrographical field research), PWN. Warszawa: 167-169 (in Polish).

Das Reichsamt für Landesaufnahme und seine Kartenwerke 1931, Verlag des Reichsamts für Landesaufnahme/ Berlin NW 40.

Klein E., Berg E.E., Dial R., 2005, Wetland drying and succession across the Kenai Peninsula Lowlands, southcentral Alaska. Canadian Journal of Forest Research 35: 1931-1941.

Kowalewski G., 2001, Transformation of wetlands and lakes at the zone of influence of Koronowski Reservoir. Limnological Review 1: 165-172. 
Kowalewski G., 2002, Borders of Tuchola Pinewoods. [in:] Banaszak J., Tobolski K. (eds) «Bory Tucholskie» National Park on the background of projected biosphere reserve: 121-138. Homini, Charzykowy (in Polish with English summary).

Kowalewski G., 2003. Shoreline changes of basins in the mire-lake reserves in S Tuchola Pinewoods. Limnological Review 3: 119-126.

Kowalewski G., Milecka K. 2003. Palaeoecology of basins of organic sediment accumulation in the Reserve Dury. Studia Quaternaria, vol. 20: 73-82.

Kowalewski G., Barabach J., 2010, Struktura osadów zbiornika jeziorno-torfowiskowego Dury V (Bory Tucholskie). Studia Limnologica et Telmatologica 4: 65-74.

Kowalewski G. Żurek S., 2011, Geology and developmental pathways of Sphagnum peatland-lake ecosystems in eastern Pomerania. Studia Quaternaria 28: 41-52.

Marszelewski W., Adamczyk A., 2004, Changes in the area of the Mazurian Lakes in the light of the cartographic materials at the scale 1:25000. Limnological Review 4: 167-176.

Parsekian A. D., Jones B. M., Jones M., Grosse G., Anthony K. M. W,. Slater L., 2011, Expansion rate and geometry of floating vegetation mats on the margins of thermokarst lakes, northern Seward Peninsula, Alaska, USA. Earth Surf. Process. Landforms 36: 1889-1897
Riordan B., Verbyla D., McGuire A.D., 2006, Shrinking ponds in subarctic Alaska based on 1950-2002 remotely sensed images. Journal Of Geophysical Research 111:.

Roach J., Griffith B., Verbyla D., Jones J., 2011, Mechanisms influencing changes in lake area in Alaskan boreal forest. Global Change Biology 17: 2567-2583.

Smith L.C., Sheng Y., MacDonald G.M., Hinzman L.D., 2005, Disappearing arctic lakes. Science 308: 1429.

Taro A., Warner B.G., Sherry L.S., 2005, Effects of shallow flooding on vegetation and carbon pools in boreal peatlands. Applied Vegetation Science 8: 199-208.

Tobolski K., 2003, Peatlands of Świecie District (original: Torfowiska na przykładzie Ziemi Świeckiej). Towarzystwo Przyjaciół Dolnej Wisły, Świecie (in Polish).

Turczyński M., Sobolewski W., Mięsiak-Wójcik K., 2009, Selected problems related to the demarcation of lake range in the light of field surveys. Lim. Rev. 9: 203-214.

Yoshikawa K., Hinzman L.D., 2003, Shrinking thermokarst ponds and groundwater dynamics in discontinuous permafrost near Council, Alaska. Permafrost and Periglacial Processes 14: 151-160. 